\title{
Perilaku Aktivitas Fisik dan Determinannya pada Mahasiswa Fakultas Ilmu - Ilmu Kesehatan Universitas Muhammadiyah Prof. Dr. Hamka
}

\section{The Behavior of Physical Activity and Determinants of Student at Faculty Health Science, University of Muhammadiyah Prof. Dr. Hamka}

\author{
Yoli Farradika(1), Yuyun Umniyatun ${ }^{(2)}$, Mochamad Iqbal Nurmansyah ${ }^{(3)}$, Miftahul Jannah ${ }^{(4)}$ \\ ${ }^{(1)(2)}$ Fakultas Ilmu - Ilmu Kesehatan, Universitas Muhammadiyah Prof Dr. Hamka Jakarta, Indonesia \\ ${ }^{(3)}$ Fakultas Ilmu Kesehatan, UIN Syarif Hidayatullah Jakarta, Indonesia \\ ${ }^{(4)}$ Jurusan Kesehatan, Politeknik Negeri Jember, Indonesia
}

Korespondensi Penulis: Yoli Farradika, Program Studi Kesehatan Masyarakat, Fakultas Ilmu - Ilmu Kesehatan, Universitas Muhammadiyah Prof Dr. Hamka Jakarta Email: yoli.epid07@gmail.com

\begin{abstract}
ABSTRAK
Berdasarkan data dari Riset Kesehatan Dasar (Riskesdas) 2013 kelompok remaja hingga dewasa muda (15-24) memiliki gaya hidup tidak aktif (sedentary/kurang beraktivitas fisik) sebesar 52\%. Kurangnya aktivitas fisik dapat menyebabkan risiko kesehatan terutama timbulnya komplikasi penyakit tidak menular seperti obesitas, diabetes, hipertensi dan gangguan jantung. Penelitian ini bertujuan untuk mengetahui hubungan aktivitas fisik dan determinannya. Penelitian ini menggunakan metode kuantitatif dengan desain studi potong lintang. Sejumlah 846 mahasiswa Fikes Uhamka berpartisipasi dalam penelitian ini. Data dikumpulkan dengan mengisi sendiri kuesioner oleh mahasiswa. Analisis data menggunakan uji chi square untuk mengetahui hubungan antara aktifitas fisik dengan determinannya dan regresi logistic untuk mengetahui prediktor dari aktifitas fisik. Penelitian ini memberikan hasil bahwa rata-rata skor Metabolic Equivalent (MET) adalah 1420,33 $\pm 2384,297$. Responden yang memiliki aktivitas fisik yang rendah sebesar 47,8\%, aktivitas fisik sedang sebesar 39,6\% dan aktivitas fisik tinggi hanya 12,6\% responden. Ada hubungan yang bermakna antara jenis kelamin, status pekerjaan, ketersediaan fasilitas olahraga, dukungan dosen, dan persepsi terhadap olahraga terhadap aktivitas fisik. Aktivitas fisik aktif lebih banyak ditemui pada responden kelamin laki-laki, mahasiswa yang sudah bekerja, ketersediaan sarana olahraga di rumah atau lingkungan sekitar, adanya ajakan dosen untuk berolahraga dan adanya persepsi yang baik terhadap olahraga. Hasil penelitian juga menunjukkan bahwa responden yang tidak bekerja, tidak terdapat fasilitas olahraga di rumah, dan mempunyai persepsi yang kurang baik terhadap olahraga adalah prediktor untuk memiliki aktivitas fisik pasif/ringan.
\end{abstract}

Kata Kunci : Persepsi, Sikap, Lingkungan, Sarana Olahraga, Aktivitas Fisik Mahasiswa

\begin{abstract}
Based on data from the 2013 Basic Health Research (Riskesdas) groups of adolescents to young adults (1524) have sedentary lifestyles (sedentary / lack of physical activity) of 52\%. Lack of physical activity can lead to health risks especially the complications of non-communicable diseases such as obesity, diabetes, hypertension and heart problems. This study aims to determine the relationship of physical activity and its determinants. This study uses a quantitative method with a cross-sectional study design. A total of 846 FIKES UHAMKA students participated in this study. Data collected by filling out the questionnaire by students. Data analysis used the chi square test to determine the relationship between physical activity and its determinants and logistic regression to determine the predictors of physical activity. This study provides results that the average Metabolic Equivalent (MET) score is $1420.33 \pm 2384.297$. Respondents who have low physical activity by $47.8 \%$, moderate physical activity by $39.6 \%$ and high physical activity by only $12.6 \%$ of respondents. There is a significant relationship between gender, work status, availability of sports facilities, lecturer support, and perception of sports on physical activity. Active physical activity is more common in male sex respondents, students who are already working, the availability of sports facilities at home or the surrounding environment, the invitation of lecturers to exercise and a good perception of sports. The results also showed that respondents who did not work, did not have sports facilities at home, and had a poor perception of sports were predictors of having passive / mild physical activity.
\end{abstract}

Keywords : Perception, Attitude, Environment, Sports Facilities, Physical Activity of Students 


\section{PENDAHULUAN}

Kesehatan global dipengaruhi oleh tiga tren yakni penuaan populasi, urbanisasi yang tidak terencana dan globalisasi dimana kesemuanya disebabkan oleh perilaku dan lingkungan yang tidak sehat (WHO, 2007). Hasilnya, terdapat peningkatan penyakit tidak menular dan faktor risikonya yang menjadi isu global yang tidak hanya mempengaruhi negara maju namun juga negara ekonomi menengah dan bawah. Hampir $45 \%$ penyakit dewasa di negara ekonomi menengah dan bawah disebabkan oleh penyakit tidak menular. Peningkatan penyakit tidak menular salah satunya disebabkan oleh perilaku masyarakat yang tidak sehat, seperti pola makan yang tidak seimbang dan akitivitas fisik kurang (WHO, 2007).

World Health Organization menyebutkan bahwa aktivitas fisik ialah segala bentuk pergerakan badan yang diproduksi oleh otot skeletal yang membutuhkan pengeluaran energi. Tidak melakukan aktivitas fisik diidentifikasi menjadi penyebab tertinggi keempat terhadap mortalitas global (6\% kematian global) (WHO, 2017). Berbagai manfaat didapatkan dari aktivitas fisik dimana diantaranya ialah dapat menurunkan risiko penyakit jantung koroner, stroke, diabetes, hipertensi, kanker kolon, kanker paudara dan depresi. Selain itu, aktivitas fisik merupakan kunci dari pengeluaran energi yang sangat penting dalam rangka menyeimbangkan energi dan kontrol berat badan bagi seseorang (Guilbert, 2003).

Di Indonesia, menurut data Riset Kesehatan Dasar (Riskesdas), pada tahun 2013 ditemukan bahwa di 22 provinsi yang ada di Indonesia, terdapat penduduk yang memiliki prevalensi aktivitas fisik tergolong kurang aktif, dan data tersebut berada di atas rata-rata penduduk yang ada di seluruh Indonesia. Hal ini dapat dilihat dengan adanya 5 daerah tertinggi dengan penduduk yang memiliki aktivitas fisik yang kurang aktif, yaitu Provinsi DKI Jakarta (44,2\%), Papua (38,9\%), Papua Barat (37,8\%), Sulawesi Tenggara dan Aceh (37,2\%) (Riskesdas, 2013).

Penelitian yang menganalisis hubungan antara pola makan, aktivitas fisik dan gaya hidup sedentari dengan overweight di SMA Negeri 5 Surabaya menunjukkan bahwa responden dengan aktivitas fisik ringan dan sedang memiliki proporsi status gizi overweight lebih banyak dan terdapat hubungan signifikan antara aktivitas fisik dengan overweight (Putra, 2017). Penelitian tentang aktivitas fisik, stress dan obesitas pada Pegawai Negeri Sipil di Sekretariat Jenderal Kementerian Kesehatan RI memberikan hasil bahwa pada tahun 2013, hampir separuh PNS mengalami kelebihan berat badan atau obesitas $(48,3 \%)$ dan sebagian besar responden biasa melakukan aktivitas fisik ringan (33,9\%) dan sedang $(36,5 \%)$. Penelitian ini memperlihatkan adanya hubungan bermakna antara aktivitas fisik dengan kejadian obesitas, yaitu semakin berat aktivitas fisik maka semakin rendah risiko obesitas (Widiantini \& Tafal, 2014).

Penelitian yang mengukur faktor risiko yang berhubungan dengan obesitas remaja pada mahasiswa FIK Universitas Siliwangi tahun 2016 memberikan hasil bahwa aktivitas fisik berpengaruh terhadap obesitas pada remaja, yaitu responden yang beraktivitas fisik kurang berisiko obesitas 6,833 kali lebih besar daripada yang beraktivitas fisik cukup (Kosnayani \& Aisyah, 2016). Penelitian tentang faktor-faktor yang mempengaruhi motivasi mahasiswa dalam melakukan aktivitas fisik di Sekolah Tinggi Ilmu Kesehatan Muhammadiyah Samarinda menunjukkan bahwa motivasi untuk melakukan aktivitas fisik dipengaruhi oleh faktor intrinsik dan faktor ekstrinsik. Kesimpulan penelitian ini adalah faktor intrinsik dan ekstrinsik yang mempengaruhi motivasi mahasiswa untuk melakukan aktivitas fisik adalah jenis kelamin, intensitas aktivitas fisik, dan faktor motivasi internal (Ismahmudi, 2015).

Generasi muda memegang peranan penting dalam pembangunan bangsa Indonesia mengingat secara demografis Indonesia akan mengalami bonus demografi atau masa emas pada rentang tahun 2020-2030. Tentunya terdapat prasyarat agar para remaja dapat memanfaatkan masa emas tersebut dimana salah satu prasyaratnya ialah kondisi sehat. Tanpa adanya kondisi sehat, para remaja yang berada pada usia produktif akan terancam tidak bisa berkontribusi terhadap pembangunan sosial dan ekonomi bangsa. Atas dasar tersebut dan hasil studi terdahulu, pentingnya dilakukan sebuah penelitian untuk melihat gambaran aktivitas fisik serta determinan perilaku tersebut dikalangan 
mahasiswa Fakultas Ilmu-Ilmu Kesehatan, Universitas Muhammadiyah Prof. Dr. Hamka.

\section{METODE}

Metode penelitian ini menggunakan metode kuantitatif dengan desain potong lintang. Lokasi penelitian adalah Fakultas Ilmu-Ilmu Kesehatan, Universitas Muhammadiyah Prof. Dr. Hamka yang dilaksanakan pada bulan September 2018 - Februari 2019. Populasi dalam penelitian ini ialah seluruh mahasiswa Fakultas Ilmu - Ilmu Kesehatan, Universitas Muhammadiyah Prof. Dr. Hamka. Sampel adalah seluruh mahasiswa di Fakultas Ilmu - Ilmu Kesehatan Universitas Muhammadiyah Prof. Dr. Hamka yang terdiri dari tiga program studi yakni kesehatan masyarakat, ilmu gizi dan teknik kardiovaskular. Jumlah sampel penelitian adalah 997 mahasiswa.

Variabel dependen dalam penelitian ini ialah perilaku aktivitas fisik mahasiswa yang diklasifikasikan berdasarkan MET (Metabolic Equivalent). Sementara variabel independennya ialah karakteristik demografi, keberadaan sarana olahraga, lingkungan sosial dan persepsi mahasiswa terhadap aktivitas fisik. Cara pengumpulan data dilakukan dengan mengisi sendiri kuesioner oleh mahasiswa. Instrumen penelitian menggunakan Global Phsycal Activity Questionnaire yang dirancang oleh World Health Organization yang terdiri dari beberapa bagian yakni karakteristik demografi, karakteristik aktivitas fisik, karakteristik lingkungan sosial dan persepsi terhadap perilaku aktivitas fisik. Analisis data yang dilakukan adalah analisis bivariat, dan multivariat. Analisis bivariat menggunakan uji chi square untuk mengetahui hubungan antara aktifitas fisik dengan determinannya. Sementara analisis multivariat menggunakan uji regresi logistik untuk mengetahui prediktor dari aktifitas fisik.

\section{HASIL}

Dari total sampel di dalam penelitian ini, hanya 846 sampel yang diikutkan dalam analisis data karena adanya ketidaklengkapan data.

Tabel 1. Karakteristik Demografi Subjek Penelitian

\begin{tabular}{lcc}
\hline \multicolumn{1}{c}{ Variabel } & n & \% \\
\hline Program Studi $(\mathrm{n}=843)$ & 452 & 53,6 \\
Kesehatan Masyarakat & 391 & 46,4 \\
Ilmu Gizi & 791 & \\
\hline Jenis Mahasiswa & 16 & 93,5 \\
Regular & 39 & 1,9 \\
Intensif & & 4,6 \\
Konversi & 117 & 13,8 \\
\hline Jenis Kelamin & 729 & 86,2 \\
Laki - laki & & \\
Perempuan & 831 & 98,2 \\
\hline Agama (n=840) & 9 & 1,8 \\
Islam & & \\
Non Islam & 684 & 80,9 \\
\hline Status Tempat Tinggal & 33 & 3,9 \\
Tinggal bersama orang tua & 3 & 0,3 \\
Tinggal bersama saudara & 1 & 0,1 \\
Tinggal bersama suami/istri & 125 & 14,8 \\
Tinggal bersama orang tua dan suami/istri & & \\
Kos/kontrak sendiri & 49 & 5,8 \\
\hline Status Pekerjaan & 797 & 94,2 \\
Bekerja & & \\
Tidak Bekerja & 832 & 98,3 \\
\hline Status Pernikahan & 14 & 1,7 \\
Belum Menikah & & \\
Menikah & & \\
\hline
\end{tabular}


Subjek penelitian ini terdiri dari mahasiswa yang lebih dari separuhnya merupakan mahasiswa Prodi Kesehatan Masyarakat $(53,4 \%)$ dan sisanya merupakan mahasiswa Prodi Ilmu Gizi (46,2\%). Sebagian besar mahasiswa tersebut merupakan mahasiswa dengan program kelas regular $(93,5 \%)$, karena program kelas reguler memiliki daya tampung yang lebih banyak di FIKES UHAMKA. Perkuliahan pada program kelas regular lebih padat daripada program kelas intensif dan konversi, yaitu dimulai dari pagi hingga sore hari dan dilaksanakan setiap hari. Oleh karena itu, sebagian besar responden dalam penelitian ini tidak bekerja $(94,2 \%)$. Responden yang telah bekerja, sebagian besar mereka bekerja sebagai karyawan swasta. Selain itu, terdapat juga yang bekerja sebagai Pegawai Negeri Sipil (PNS), buruh, dan wiraswasta.
Sebagian besar responden juga memiliki jenis kelamin perempuan $(86,2 \%)$ serta beragama Islam $(98,2 \%)$. Lebih dari dua pertiga responden $(80,9 \%)$ tinggal bersama orang tua dan berstatus belum menikah (98,3\%) (Tabel 1).

Rata - rata skor MET dalam penelitian ini adalah $1420.33 \pm 2384.297$. Hampir setengah dari responden memiliki aktivitas fisik yang rendah $(47,8 \%)$, sedangkan mahasiswa dengan aktivitas fisik tinggi memiliki persentase yang kecil (12,6 $\%)$. Aktivitas fisik dengan klasifikasi tinggi dan sedang dikelompokkan dalam kategori aktif, sedangkan aktivitas fisik rendah dikelompokkan dalam kategori pasif (Gambar 1) (Riskesdas, 2013).

Penelitian ini menunjukkan bahwa lebih dari setengah responden tidak memiliki fasilitas olahraga di rumah dan sekitarnya. Sebagian

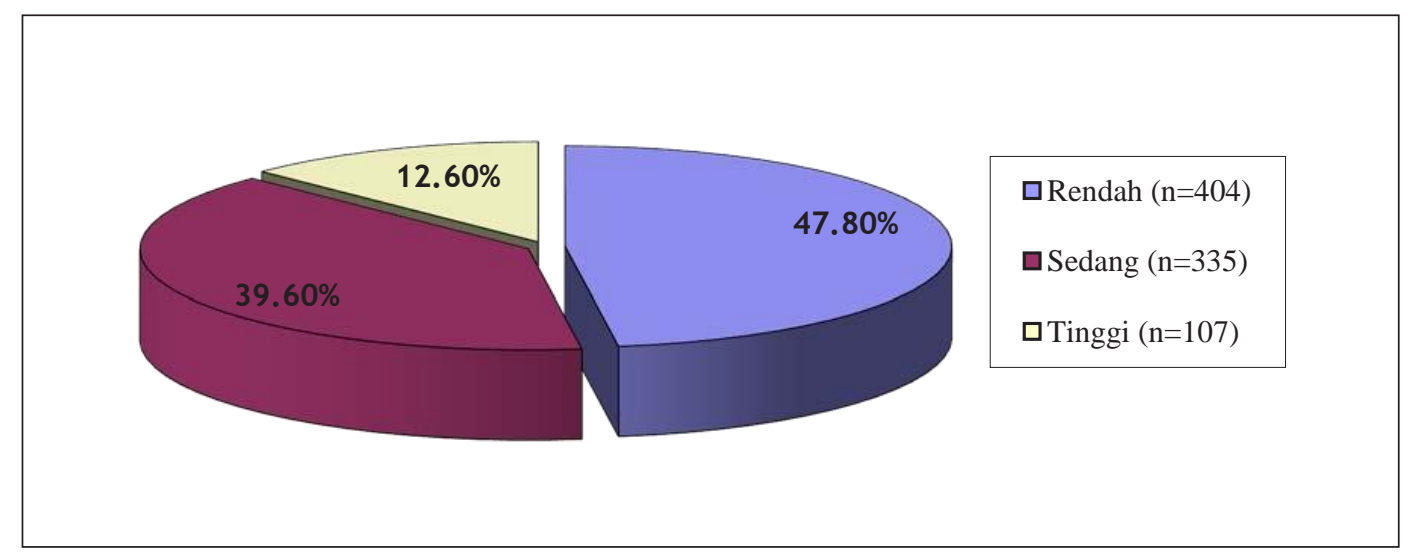

Gambar 1. Tingkat Aktivitas Fisik Mahasiswa

Tabel 2. Dukungan Sosial dan Lingkungan Terhadap Aktivitas Fisik

\begin{tabular}{lcc}
\hline \multicolumn{1}{c}{ Variabel } & n & \% \\
\hline Ketersediaan Fasilitas Olahraga di Rumah & & \\
Tidak & 548 & 64,8 \\
Ya & 298 & 35,2 \\
Penggunaan Kendaraan Bermotor & 599 & \\
Ya & 247 & 70,8 \\
Tidak & & 29,2 \\
Ajakan Teman untuk Berolahraga & 475 & \\
Tidak & 371 & 56,1 \\
Ya & & 43,9 \\
Ajakan Keluarga untuk Berolahraga & 449 & \\
Tidak & 397 & 53,1 \\
Ya & & 46,9 \\
Ajakan Dosen untuk Berolahraga & 571 & \\
Tidak & 275 & 67,5 \\
Ya & & 32,5 \\
\hline
\end{tabular}




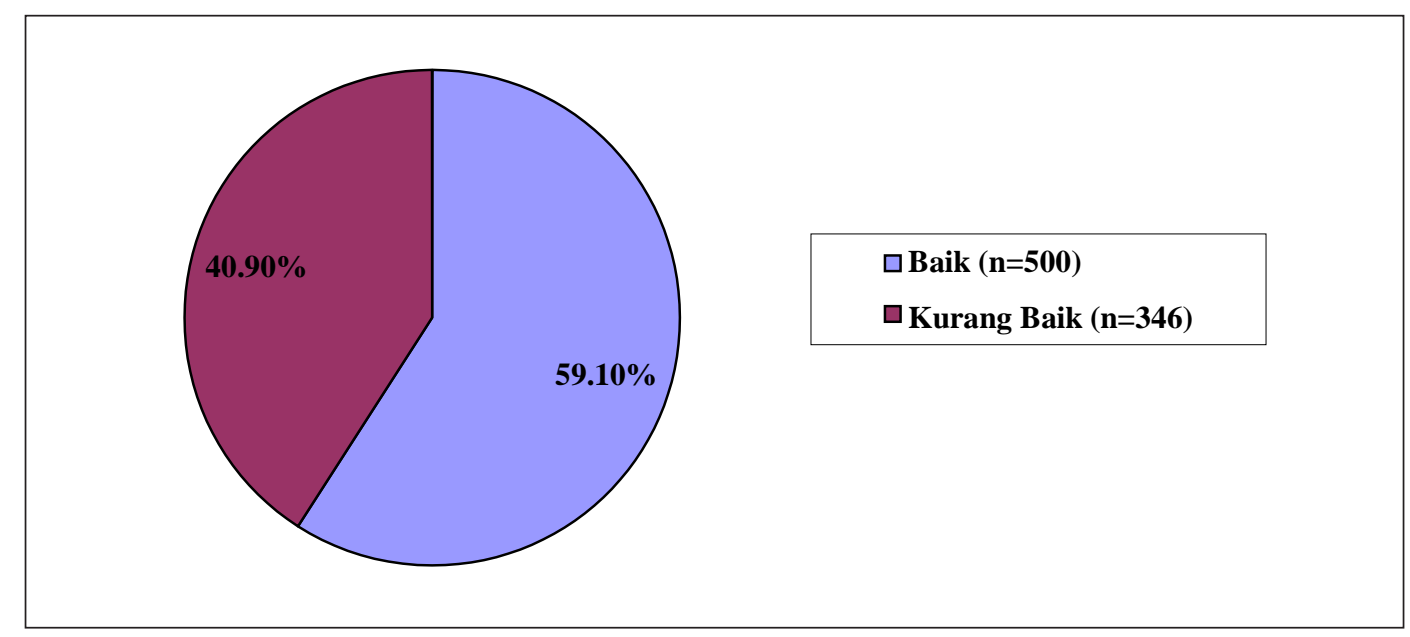

Gambar 2. Persepsi Terhadap Aktivitas Fisik

Tabel 3. Aspek Persepsi Terhadap Aktivitas Fisik

\begin{tabular}{|c|c|c|c|c|}
\hline \multirow{2}{*}{ Persepsi Terhadap Aktivitas Fisik } & \multicolumn{2}{|c|}{ Setuju } & \multicolumn{2}{|c|}{ Tidak Setuju } \\
\hline & $\mathbf{n}$ & $\%$ & $\mathbf{n}$ & $\%$ \\
\hline $\begin{array}{l}\text { Aktivitas fisik sangat penting bagi pemeliharaan } \\
\text { kesehatan fisik dan mental }\end{array}$ & 829 & 98,0 & 17 & 2,0 \\
\hline $\begin{array}{l}\text { Aktivitas fisik dapat dilakukan dengan } \\
\text { melakukan kegiatan sehari - hari }\end{array}$ & 816 & 96,5 & 30 & 3,5 \\
\hline $\begin{array}{l}\text { Aktivitas fisik dilakukan teratur minimal } 30 \\
\text { menit setiap hari }\end{array}$ & 743 & 87,8 & 103 & 12,2 \\
\hline Melakukan aktivitas fisik terasa berat & 238 & 28,1 & 608 & 71,9 \\
\hline $\begin{array}{l}\text { Melakukan aktivitas fisik tidak penting untuk } \\
\text { dilakukan mengingat saat ini sedang dalam } \\
\text { kondisi sehat }\end{array}$ & 130 & 15,4 & 716 & 84,6 \\
\hline $\begin{array}{l}\text { Tidak melakukan olahraga karena tidak } \\
\text { memiliki waktu luang }\end{array}$ & 324 & 38,3 & 522 & 61,7 \\
\hline $\begin{array}{l}\text { Adanya teman berolahraga menjadi } \\
\text { penyemangat saya untuk berolahraga }\end{array}$ & 747 & 88,3 & 99 & 11,7 \\
\hline $\begin{array}{l}\text { Adanya program olahraga (peregangan) bersama } \\
\text { diselenggarakan oleh kampus dapat mendorong } \\
\text { saya untuk melakukan olahraga }\end{array}$ & 644 & 76,1 & 202 & 23,9 \\
\hline
\end{tabular}

responden menyatakan bahwa teman, keluarga dan dosen tidak memberikan motivasi dalam berolahraga. Selain itu, penggunaan sepeda motor di kalangan mahasiswa masih cukup tinggi, hampir tiga perempat responden masih sering menggunakan sepeda motor untuk beraktivitas (Tabel 2). Pada penelitian ini juga menunjukkan bahwa lebih dari 50\% responden sudah memiliki persepsi yang baik terkait aktivitas fisik, dimana sebagian besar responden menyadari bahwa aktivitas fisik sangat penting untuk kesehatan (Gambar 2).
Hasil penelitian menunjukkan bahwa sebagian besar responden menyetujui bahwa aktivitas sangat penting untuk kesehatan $(98, \%)$, dapat dilakukan dalam kegiatan sehari-hari (96,5\%), dilakukan teratur minimal 30 menit setiap hari $(87,8)$, adanya teman berolahraga dapat menjadi penyemangat dalam berolahraga $(88,3 \%)$, dan adanya peregangan di kampus dapat mendorong responden untuk berolahraga (76,1\%) (Tabel 3).

Hasil penelitian menunjukkan bahwa ada hubungan yang bermakna antara aktivitas 
fisik dengan jenis kelamin. Responden dengan jenis kelamin perempuan cenderung melakukan aktivitas fisik pasif $(49,5 \%)$ dibanding responden laki-laki (36,8\%). Begitu pula dengan status pekerjaan, penelitian ini menunjukkan bahwa ada hubungan yang bermakna antara aktivitas fisik dengan status pekerjaan. Responden yang bekerja cenderung melakukan aktivitas fisik aktif $(81,6 \%)$ dibandingkan responden yang tidak bekerja $(50,4 \%)$. Penelitian ini juga menunjukkan bahwa ada hubungan yang bermakna antara aktivitas fisik dengan ketersediaan sarana olahraga di rumah atau lingkungan sekitar. Responden yang mempunyai sarana olahraga di rumah dan lingkungan sekitar cenderung melakukan aktivitas fisik aktif $(60,4 \%)$ dibanding responden yang tidak mempunyai sarana olahraga di rumah dan lingkungan sekitar (47,8\%) (Tabel 4).
Lingkungan sosial yang diteliti meliputi adanya dukungan teman, dukungan keluarga, dukungan dosen dan penggunaan motor seharihari. Penelitian ini menunjukkan bahwa ada hubungan yang bermakna antara aktivitas fisik dengan dukungan dosen. Adanya dukungan dosen mempengaruhi 58,5\% responden untuk melakukan aktivitas fisik aktif.

Penelitian ini menunjukkan bahwa ada hubungan yang bermakna antara aktivitas fisik dengan persepsi terhadap olahraga. Responden yang memiliki persepsi yang baik terhadap olahraga lebih banyak melakukan aktivitas fisik yang aktif $(57,2 \%)$ dibandingkan responden yang memiliki persepsi kurang baik $(45,1 \%)$ (Tabel 4).

Berdasarkan analisis multivariat, status tempat tinggal, status pekerjaan, ketersediaan fasilitas olahraga di rumah, dan persepsi terhadap

Tabel 4. Hubungan Antara Aktivitas Fisik dan Determinannya

\begin{tabular}{|c|c|c|c|}
\hline Variabel & $\begin{array}{r}\text { Aktivitas Pasif } \\
\mathbf{n}(\%) \\
\end{array}$ & $\begin{array}{r}\text { Aktivitas Aktif } \\
\mathbf{n}(\%) \\
\end{array}$ & p value \\
\hline $\begin{array}{l}\text { Jenis Kelamin } \\
\text { Perempuan } \\
\text { Laki - laki }\end{array}$ & $\begin{array}{r}361(49.5) \\
43(36.8)\end{array}$ & $\begin{array}{r}368(50.5) \\
74(63.2)\end{array}$ & $0.01^{*}$ \\
\hline $\begin{array}{l}\text { Status Tempat Tinggal } \\
\text { Kos/Kontrak/Asrama } \\
\text { Tinggal bersama orang tua/saudara/suami/istri }\end{array}$ & $\begin{array}{r}50(40) \\
354(49.1)\end{array}$ & $\begin{array}{r}75(60) \\
367(50.9)\end{array}$ & 0.06 \\
\hline $\begin{array}{l}\text { Status Pernikahan } \\
\text { Belum Menikah } \\
\text { Menikah }\end{array}$ & $\begin{array}{r}395(47.5) \\
9(64.3)\end{array}$ & $\begin{array}{r}437(52.5) \\
5(35.7)\end{array}$ & 0.212 \\
\hline $\begin{array}{l}\text { Status Pekerjaan } \\
\text { Tidak Bekerja } \\
\text { Bekerja }\end{array}$ & $\begin{array}{r}395(49.6) \\
9(18.4)\end{array}$ & $\begin{array}{r}402(50.4) \\
40(81.6)\end{array}$ & $<0.001^{*}$ \\
\hline $\begin{array}{l}\text { Ketersediaan Fasilitas Olahraga di Rumah } \\
\text { Tidak } \\
\text { Ya }\end{array}$ & $\begin{array}{l}286(52.2) \\
118(39.6)\end{array}$ & $\begin{array}{l}262(47.8) \\
180(60.4)\end{array}$ & $<0.001^{*}$ \\
\hline $\begin{array}{l}\text { Dukungan Teman Berolahraga } \\
\text { Tidak } \\
\text { Ya }\end{array}$ & $\begin{array}{l}239(50.3) \\
165(44.5)\end{array}$ & $\begin{array}{l}236(49.7) \\
206(55.5)\end{array}$ & 0.091 \\
\hline $\begin{array}{l}\text { Dukungan Keluarga Berolahraga } \\
\text { Tidak } \\
\text { Ya }\end{array}$ & $\begin{array}{l}225(50.1) \\
179(45.1)\end{array}$ & $\begin{array}{l}224(49.9) \\
218(54.9)\end{array}$ & 0.144 \\
\hline $\begin{array}{l}\text { Dukungan Dosen Berolahraga } \\
\text { Tidak } \\
\text { Ya }\end{array}$ & $\begin{array}{l}290(50.8) \\
114(41.5)\end{array}$ & $\begin{array}{l}281(49.2) \\
161(58.5)\end{array}$ & $0.011^{*}$ \\
\hline $\begin{array}{l}\text { Penggunaan Motor Sehari - hari } \\
\text { Ya } \\
\text { Tidak }\end{array}$ & $\begin{array}{l}286(47.7) \\
118(47.8)\end{array}$ & $\begin{array}{l}313(52.3) \\
129(52.2)\end{array}$ & 0.994 \\
\hline $\begin{array}{l}\text { Persepsi terhadap Olahraga } \\
\text { Kurang Baik } \\
\text { Baik }\end{array}$ & $\begin{array}{l}190(54.9) \\
214(42.8)\end{array}$ & $\begin{array}{l}156(45.1) \\
286(57.2)\end{array}$ & $0.001^{*}$ \\
\hline
\end{tabular}


Tabel 5. Prediktor Aktivitas Fisik

\begin{tabular}{|c|c|c|c|c|}
\hline Variabel & $\begin{array}{c}\text { Crude OR } \\
(95 \% \text { CI })\end{array}$ & $p$ value & $\begin{array}{l}\text { Adjusted OR } \\
\quad \text { (95\% CI) }\end{array}$ & p value \\
\hline $\begin{array}{l}\text { Jenis Kelamin } \\
\text { Perempuan } \\
\text { Laki }- \text { laki }\end{array}$ & $\begin{array}{c}1.688 \\
(1.128-2.526)\end{array}$ & 0.01 & $\begin{array}{c}1.495 \\
(0.978-2.287)\end{array}$ & 0.064 \\
\hline $\begin{array}{l}\text { Status Tempat Tinggal } \\
\text { Kos/Kontrak/Asrama } \\
\text { Tinggal bersama orang tua/saudara/suami/istri }\end{array}$ & $\begin{array}{c}0.691 \\
(0.47-1.017)\end{array}$ & 0.06 & $\begin{array}{c}0.62 \\
(0.416-0.925)\end{array}$ & $0.019^{*}$ \\
\hline $\begin{array}{l}\text { Status Pernikahan } \\
\text { Belum Menikah } \\
\text { Menikah }\end{array}$ & $\begin{array}{c}0.502 \\
(0.167-1.511)\end{array}$ & 0.212 & $\begin{array}{c}0.482 \\
(0.15-1.547)\end{array}$ & 0.22 \\
\hline $\begin{array}{l}\text { Status Pekerjaan } \\
\text { Tidak Bekerja } \\
\text { Bekerja }\end{array}$ & $\begin{array}{c}4.367 \\
(2.091-9.119)\end{array}$ & 0.00 & $\begin{array}{c}4.27 \\
(2.002-9.107)\end{array}$ & $0.00^{*}$ \\
\hline $\begin{array}{l}\text { Ketersediaan Fasilitas Olahraga di Rumah } \\
\text { Tidak } \\
\text { Ya }\end{array}$ & $\begin{array}{c}1.665 \\
(1.251-2.217)\end{array}$ & 0.00 & $\begin{array}{c}1.518 \\
(1.126-2.046)\end{array}$ & $0.006^{*}$ \\
\hline $\begin{array}{l}\text { Dukungan Teman Berolahraga } \\
\text { Tidak } \\
\text { Ya }\end{array}$ & $\begin{array}{c}1.264 \\
(0.963-1.66)\end{array}$ & 0.091 & $\begin{array}{c}0.997 \\
(0.733-1.355)\end{array}$ & 0.983 \\
\hline $\begin{array}{l}\text { Dukungan Keluarga Berolahraga } \\
\text { Tidak } \\
\text { Ya }\end{array}$ & $\begin{array}{c}1.223 \\
(0.933-1.604)\end{array}$ & 0.144 & $\begin{array}{c}1.081 \\
(0.797-1.465)\end{array}$ & 0.617 \\
\hline $\begin{array}{l}\text { Dukungan Dosen Berolahraga } \\
\text { Tidak } \\
\text { Ya }\end{array}$ & $\begin{array}{c}1.458 \\
(1.09-1.949)\end{array}$ & 0.011 & $\begin{array}{c}1.314 \\
(0.965-1.788)\end{array}$ & 0.083 \\
\hline $\begin{array}{l}\text { Persepsi terhadap Olahraga } \\
\text { Kurang Baik } \\
\text { Baik }\end{array}$ & $\begin{array}{c}1.628 \\
(1.235-2.145)\end{array}$ & 0.001 & $\begin{array}{c}1.584 \\
(1.186-2.116)\end{array}$ & $0.002^{*}$ \\
\hline
\end{tabular}

olahraga merupakan prediktor dari aktivitas fisik. Responden yang tidak bekerja, tidak terdapat fasilitas olahraga di rumah, dan mempunyai persepsi yang kurang baik, secara berturut turut memiliki peluang $4.367 ; 1.665 ; 1.628$ kali lebih besar untuk beraktivitas fisik pasif/ ringan dibandingkan dengan mereka yang sudah bekerja, terdapat fasilitas olahraga di rumah, dan mempunyai persepsi yang baik terhadap aktivitas fisik. Sebaliknya, responden yang tinggal di kos/ kontrakan/asrama memiliki peluang 1.447 kali lebih besar untuk terhindar memiliki aktivitas fisik pasif/ringan dibandingkan dengan mereka yang tinggal bersama keluarganya (Tabel 5).

\section{DISKUSI}

Penelitian yang dilakukan kepada mahasiswa Fakultas Kedokteran Universitas
Brawijaya menyimpulkan bahwa 60\% mahasiswa kedokteran memiliki aktivitas fisik yang rendah (Riskawati, Prabowo, \& Rasyid, 2014). Apabila dibandingkan dengan penelitian ini, tingkat mahasiswa yang beraktivitas fisik rendah lebih banyak pada mahasiswa FK Universitas Brawijaya dibandingkan mahasiswa FIKES UHAMKA. Hal tersebut dapat disebabkan adanya faktor stress, seperti yang dinyatakan oleh Koeneman et al. (2011) bahwa stress merupakan faktor penentu dari tingkat aktivitas fisik seseorang (Riskawati, Prabowo, \& Rasyid, 2014). Namun faktor tersebut tidak diteliti pada kedua penelitian ini.

Penelitian yang mengukur MET pada mahasiswa di Fakultas Pendidikan Fisik \& Olahraga Romania tahun 2015 mendapatkan hasil bahwa rata-rata MET adalah 1791,42 $\pm 771,3$. 
Mahasiswa yang melakukan aktivitas tinggi (vigorous) sebesar 53,65\%, yang melakukan aktivitas sedang (moderate) sebesar 20,7\% dan yang melakukan aktivitas ringan (light) sebesar 26,1\% (Fagarasa, Radub, \& Vanvuc, 2015). Penelitian ini menunjukkan tingkat aktivitas fisik yang berbeda dengan penelitian ini, dimana mahasiswa di FIKES UHAMKA mempunyai tingkat aktivitas fisik yang lebih rendah dibanding dengan mahasiswa di Fakultas Pendidikan Fisik \& Olahraga Romania.

Aktivitas fisik memberikan manfaat yang besar bagi mahasiswa, antara lain memberikan kebugaran dan kesehatan, memperpanjang usia, dan lain sebagainya. Namun sayangnya, tidak semua mahasiswa melakukan aktivitas fisik sesuai dengan seharusnya. Menurut Gage dan Berliner, individu yang memiliki daya dorong untuk memunculkan perilaku dan memiliki arah dari proses perilaku tersebut sehingga mampu mencapai tujuannya, maka individu tersebut dikatakan memiliki motivasi. Motivasi pada remaja untuk melakukan aktivitas fisik dapat disebabkan karena dorongan dari berbagai hal, seperti tersedianya fasilitas olahraga, adanya dukungan dari keluarga, teman, dan pihak kampus seperti dosen.

Studi yang dilakukan terhadap mahasiswa di Amerika menunjukkan bahwa dukungan sosial yang memberikan pengaruh penting pada aktivitas fisik adalah lingkungan kampus. Sehingga disarankan agar mahasiswa berjalan kaki atau menggunakan sepeda sebagai alat transportasi ke kampus. Lingkungan sosial lain yang dapat meningkatkan aktivitas fisik pada mahasiswa adalah kelompok persaudaraan (fraternity/sorority) (Kim Miller, 2005).

Studi yang dilakukan terhadap 1700 mahasiswa di Amerika tentang tingkat dan karakteristik fisik di antara kelompok mahasiswa menyebutkan bahwa jenis kelamin, ras, menjadi atlet antar perguruan tinggi, dan bagian dari kelompok persaudaraan sosial atau perkumpulan mahasiswi adalah prediktor dari aktivitas fisik tinggi (vigorous). Sedangkan prediktor aktivitas fisik sedang (moderate) adalah jenis kelamin, ras dan menjadi atlet antar perguruan tinggi. (Kim Miller, 2005). Pada penelitian terhadap mahasiswa FIKES UHAMKA jenis kelamin bukan merupakan prediktor aktivitas fisik.

\section{KESIMPULAN}

Hasil penelitian ini menemukan bahwa rata - rata skor Metabolic Equivalent (MET) dalam penelitian ini adalah $1420.33 \pm 2384.297$. Hal ini menunjukkan bahwa sebesar $47,8 \%$ responden memiliki aktivitas fisik yang rendah, $39,6 \%$ responden memiliki aktivitas fisik sedang dan hanya $12,6 \%$ responden melakukan aktivitas fisik tinggi. Hasil penelitian juga menemukan bahwa terdapat hubungan yang bermakna antara jenis kelamin, status pekerjaan, dukungan dosen dan persepsi terhadap olahraga terhadap aktivitas fisik. Aktivitas fisik aktif ditemui pada jenis kelamin laki-laki, mahasiswa yang sudah bekerja, ketersediaan sarana olahraga di rumah atau lingkungan sekitar, adanya ajakan dosen untuk berolahraga, dan adanya persepsi yang baik terhadap olahraga. Hasil penelitian juga menunjukkan bahwa responden yang tidak bekerja, tidak terdapat fasilitas olahraga di rumah, dan mempunyai persepsi yang kurang baik terhadap olahraga adalah prediktor responden untuk memiliki aktivitas fisik pasif/ringan.

Dengan ditemukannya hubungan antara ketersediaan sarana olahraga dengan tingkat aktivitas fisik mahasiswa disarankan agar FIKES UHAMKA memiliki sarana olahraga, karena sejak dibuka pada tahun 1998 sampai saat ini FIKES UHAMKA tidak memiliki sarana olahraga. Selain itu, aktivitas fisik mahasiswa FIKES UHAMKA yang rendah sebaiknya dapat ditingkatkan dengan memberikan motivasi melalui program promosi kesehatan secara lebih aktif dengan melibatkan para dosen dan mahasiswa peminatan Promosi dan Pendidikan Kesehatan (Prodikes). Selanjutnya, meningkatkan kegiatan olahraga/kompetisi olahraga antar mahasiswa baik ditingkat fakultas maupun di tingkat universitas melalui himpunan organisasi kemahasiswaan yang ada.

\section{DAFTAR PUSTAKA}

Fagarasa, Simona-Pia, Liliana-Elisabeta Radub and Gynetta Vanvuc. (2015). "The Level of Physical Activity of University Students." Procedia - Social and Behavioral Sciences 197: 1454-1457.

Guilbert, J-J. (2003). "The World Health Report 2002: reducing risks, promoting healthy life". Education for Health. 
Ismahmudi, Ramdhany. (2015) "Faktor-Faktor yang Mempengaruhi Motivasi Mahasiswa dalam Melakukan Aktivitas Fisik di Sekolah Tinggi Ilmu Kesehatan Muhammadiyah Samarinda." Electronic Theses \& Dissertations. Universitas Gadjah Mada.

Kim Miller, Ruth R. Staten, Mary Kay Rayens, and Melody Noland. (2015). "Levels and Characteristics of Physical Activity Among a College Student Cohort." American Journal of Health Education : 215-220.

Kosnayani, Ai Sri and Iseu Siti Aisyah. (2016). "Faktor Risiko Yang Berhubungan Dengan Obesitas Remaja”. Jurnal Siliwangi : 127-130.

Putra, Wismoyo Nugraha. (2017). "Hubungan Pola Makan, Aktivitas Fisik Dan Aktivitas Sedentari Dengan Overweight Di SMA Negeri 5 Surabaya". Jurnal Berkala Epidemiologi : 297-310.

Riskawati, Yhusi Karina, Edwin Damar Prabowo and Harun AL Rasyid. (2014). "Tingkat Aktivitas Fisik Mahasiwa Program Studi Pendidikan Dokter Tahun Kedua, Ketiga, Keempat”. Journal of Behavior, Health and Social 6 (2) : 35-44.

Riskesdas. (2013). "Riset Kesehatan Dasar 2013". Laporan Nasional 2013. <http://doi.org/1 Desember 2013>.

WHO. (2007). "a Guide for Population Based Approaches to Increasing Levels of Physical Activity: Implementation of the WHO Strategy on Diet, Physical Activity and Health": 24.

—. . (2017). "Physical activity". <https://www.who. int/dietphysicalactivity/pa/en/>.

Widiantini, Winne and Zarfiel Tafal. (2014). "Aktivitas Fisik, Stres, dan Obesitas pada Pegawai Negeri". Jurnal Kesehatan Masyarakat Nasional : 330-336. 